\title{
Plasma leptin is related to proinflammatory status and dietary intake in patients with chronic obstructive pulmonary disease.
}

Citation for published version (APA):

Schols, A. M. W. J., Creutzberg, E. C., Buurman, W. A., Campfield, L. A., Saris, W. H. M., \& Wouters, E. F. M. (1999). Plasma leptin is related to proinflammatory status and dietary intake in patients with chronic obstructive pulmonary disease. American Journal of Respiratory and Critical Care Medicine, 160(4), 12201226. https://doi.org/10.1164/ajrccm.160.4.9811033

Document status and date:

Published: 01/01/1999

DOI:

10.1164/ajrccm.160.4.9811033

Document Version:

Publisher's PDF, also known as Version of record

Please check the document version of this publication:

- A submitted manuscript is the version of the article upon submission and before peer-review. There can be important differences between the submitted version and the official published version of record.

People interested in the research are advised to contact the author for the final version of the publication, or visit the DOI to the publisher's website.

- The final author version and the galley proof are versions of the publication after peer review.

- The final published version features the final layout of the paper including the volume, issue and page numbers.

Link to publication

\footnotetext{
General rights rights.

- You may freely distribute the URL identifying the publication in the public portal. please follow below link for the End User Agreement:

www.umlib.nl/taverne-license

Take down policy

If you believe that this document breaches copyright please contact us at:

repository@maastrichtuniversity.nl

providing details and we will investigate your claim.
}

Copyright and moral rights for the publications made accessible in the public portal are retained by the authors and/or other copyright owners and it is a condition of accessing publications that users recognise and abide by the legal requirements associated with these

- Users may download and print one copy of any publication from the public portal for the purpose of private study or research.

- You may not further distribute the material or use it for any profit-making activity or commercial gain

If the publication is distributed under the terms of Article $25 \mathrm{fa}$ of the Dutch Copyright Act, indicated by the "Taverne" license above, 


\title{
Plasma Leptin Is Related to Proinflammatory Status and Dietary Intake in Patients with Chronic Obstructive Pulmonary Disease
}

\author{
ANNEMIE M. W. J. SCHOLS, EVA C. CREUTZBERG, WIM A. BUURMAN, L. ARTHUR CAMPFIELD, \\ WIM H. M. SARIS, and EMIEL F. M. WOUTERS \\ Departments of Pulmonology, Surgery, and Human Biology, Maastricht University, Maastricht, The Netherlands; \\ and Hoffman-La Roche Inc., Nutley, New Jersey
}

\begin{abstract}
Chronic obstructive pulmonary disease (COPD) is a syndrome of chronic wasting, in part associated with a chronic inflammatory response. The aim of this study was to investigate cross-sectionally and prospectively the potential role of leptin in relation to systemic inflammation in the regulation of the energy balance in COPD. Body composition by deuterium dilution, resting energy expenditure (REE) by indirect calorimetry, and plasma concentrations of leptin and soluble tumor necrosis factor (TNF) receptors (STNF-R) 55 and 75 by ELISA were measured in 27 male patients with emphysema and 15 male patients with chronic bronchitis (disease-subtype defined by high-resolution computed tomography [HRCT]). Emphysematous patients were characterized by a lower body mass index due to a lower fat mass (FM) $(p=0.001)$ and by lower mean (detectable) leptin concentrations $(p=0.020)$ compared with bronchitic patients. Leptin was exponentially related to $F M$ in emphysema $(r=0.74$, $p<0.001)$ and in chronic bronchitis $(r=0.80, p=0.001)$. Furthermore, a significant partial correlation coefficient between leptin and STNF-R55 adjusted for FM and oral corticosteroid use was seen in emphysema $(r=0.81, p<0.001)$ but not in chronic bronchitis. In 17 predominantly emphysematous depleted male patients with COPD, baseline plasma leptin divided by FM was in addition logarithmically inversely related to baseline dietary intake $(r=-0.50, p=0.047)$ and to the degree of weight change after $8 \mathrm{wk}$ of nutritional support $(r=-0.60, p=0.017)$. This proposed cytokine-leptin link in pulmonary cachexia may explain the poor response to nutritional support in some of the cachectic patients with COPD and may open a novel approach in combating this significant comorbidity in COPD. Schols AMWJ, Creutzberg EC, Buurman WA, Campfield LA, Saris WHM, Wouters EFM. Plasma leptin is related to proinflammatory status and dietary intake in patients with chronic obstructive pulmonary disease.

AM J RESPIR CRIT CARE MED 1999;160:1220-1226.
\end{abstract}

R ecent studies suggest that leptin, a protein synthesized by adipose tissue and encoded by the ob gene (1), plays an important role in the energy balance. L eptin is postulated to represent the afferent hormonal signal to the brain including the hypothalamus in a feedback mechanism regulating the fat mass (FM ). L eptin binds to the leptin receptor (2) in the hypothalamus (3), the brain nucleus that plays a central role in the regulation of feeding behavior and energy balance. In animal models, the result of this interaction is a decrease in food intake (4). There is now evidence that the effects of leptin on food intake are mediated by two limbs of the weight control system: the appetite-stimulating peptide, neuropeptide $Y$, and the satiety-stimulating, melanocyte-stimulating hormone (5). Furthermore, leptin may mediate energy expenditure by both increasing physical activity and activity-independent thermo-

(Received in original form November 10, 1998 and in revised form April 26, 1999) Correspondence and requests for reprints should be addressed to Dr. A. M. W. J. Schols, Department of Pulmonology, University Hospital Maastricht, P.O. Box 5800, 6202 AZ Maastricht, The Netherlands. E-mail: ASC@SLON.AZM.NL

Am J Respir Crit Care Med Vol 160. pp 1220-1226, 1999

Internet address: www.atsjournals.org genesis, which in part appears to involve activation of brown adipose tissue (6).

In obesity, a central insensitivity ("resistance") to leptin has been shown (7). Conversely, tissue wasting ultimately leading to cachexia is commonly seen in chronic diseases such as chronic obstructive pulmonary disease (COPD). D ifferent patterns of chronic wasting, from massive loss of FM to disproportionate wasting of body cell mass, can be distinguished (8). These differences indicate the involvement of different regulatory mechanisms for the (disturbances in) energy and protein balance in COPD. In view of the fact that both anorexia and hypermetabolism play a role in the wasting associated with chronic pulmonary disease $(9,10)$, underlying abnormalities in the leptin feedback mechanism might also be involved. In particular, elevated concentrations of circulating leptin or, on the contrary, a hypothalamic insensitivity to a decrease in leptin concentrations might be present. The observed link between inflammatory cytokines and leptin in two experimental animal studies $(11,12)$ led to the hypothesis that adipose tissue gene expression is regulated by inflammatory cytokines, which in turn could induce anorexia in acute or chronic inflammation. Two recent reports have furthermore shown an enhanced production of tumor necrosis factor- $\alpha$ 
(TNF- $\alpha$ ) in patients with COPD suffering from weight loss $(13,14)$. Clinical data regarding the possible involvement of leptin in the pathophysiology of inflammation-associated chronic wasting are however lacking.

The present study was undertaken to investigate cross-sectionally the relationship between plasma leptin concentrations and soluble TNF receptor (STNF-R ) 55 and 75 concentrations, as a reflection of an enhanced inflammatory status, in patients with COPD stratified into emphysema and chronic bronchitis. Furthermore, in a group of depleted patients with COPD it was prospectively studied if leptin was a determining factor of dietary intake, resting energy expenditure ( $R E E)$, and the response to nutritional therapy.

\section{METHODS}

\section{Patients}

Cross-sectional study. A random group of patients with COPD, consecutively admitted to a pulmonary rehabilitation center, were included in the study when they fulfilled the following criteria: (1) COPD according to the A merican Thoracic Society guidelines (15) and chronic airflow obstruction defined as a measured forced expiratory volume in one second $\left(\mathrm{FEV}_{1}\right)$ less than $70 \%$ of the reference value; (2) irreversible obstructive airway disease, i.e., $<10 \%$ improvement in $\mathrm{FEV}_{1}$ expressed as percentage of predicted after inhalation of a $\beta_{2}$-agonist; ( 3 ) in clinically stable condition, not suffering from a respiratory tract infection; (4) no concomitant confounding diseases, such as malignant disease, gastrointestinal disorders, severe endocrine disorders or recent surgery; (5) no suspected abnormal fluid balance as manifested by the presence of edema or regular use of diuretics. In order to increase homogeneity of the study population, only male subjects were included.

P rospective study. The second group consisted of male patients with COPD fulfilling the same inclusion criteria as indicated in the cross-sectional study, and suffering from below normal body weight (body mass index [BM I; body weight $/$ height $\left.^{2}\right] \leqslant 23 \mathrm{~kg} / \mathrm{m}^{2}$ ) and/or depletion of fat-free mass (fat-free mass index [FFM I; FFM /height ${ }^{2}$ ] $16 \mathrm{~kg} / \mathrm{m}^{2}$ ). These patients received standardized nutritional therapy consisting of 500 to $750 \mathrm{kcal} / \mathrm{d}$ given as three liquid supplements of $200 \mathrm{ml}$ each, as an integrated part of an in-patient pulmonary rehabilitation program. R esponse to nutritional therapy was defined as the weight change reached after 8 wk of treatment.

The study was approved by the medical ethical committee of the $\mathrm{U}$ niversity $\mathrm{H}$ ospital of $\mathrm{M}$ aastricht. Informed consent was obtained from all subjects. A II measurements were performed during the first 2 wk after admission to the center, and in the prospective study in addition after 8 wk of nutritional treatment.

\section{Body Composition}

Body height was determined to the nearest $0.5 \mathrm{~cm}$ (L ameris W M 715; Breukelen, The N etherlands) with subjects standing barefoot. Body weight was measured with a beam scale to the nearest $0.1 \mathrm{~kg}$ (SECA, FR G, G ermany) with subjects barefoot and in light clothing. R ecent weight loss was defined as body weight loss in the last $3 \mathrm{mo}$.

To measure total body water (TBW) each patient received a weighed ( $1 \mathrm{~g} / \mathrm{L}$ estimated TBW ) oral dose of deuterium-labeled water $\left(\mathrm{D}_{2} \mathrm{O} ; 99.84\right.$ atom percentage excess) mixed into $70 \mathrm{ml}$ water in the late evening around 10:00 P.M. J ust before and approximately $10 \mathrm{~h}$ later, after complete emptying of the bladder, a urine sample was obtained. U rine was analyzed for deuterium with an isotope ratio mass spectrometer (16). D euterium dilution space was calculated from the quantity of administered $\mathrm{D}_{2} \mathrm{O}$ and the urine $\mathrm{D}_{2} \mathrm{O}$ concentrations after complete distribution. TBW was calculated from these values by applying a conversion factor of 1.04. This correction accounts for the exchange of labile hydrogen which occurs in humans during the equilibrium period. FFM was calculated assuming a hydration factor of 0.73 . FM was calculated by subtracting FFM from body weight.

In order to assess possible disturbances in body fat distribution in the cross-sectional study group, subregional FM was assessed by dualenergy $X$-ray absorptiometry ( $D X A$ ), which is a direct method of assessing bone mineral content and the soft tissue surrounding the bone
(FFM and FM). E ach patient, lying in supine position on a scan table for approximately $15 \mathrm{~min}$, was scanned by a D PX -L B one D ensitometer ( $L$ unar R adiation Corp., M adison, WI; voltage $76.0 \mathrm{kV} \mathrm{p}$, current $150 \mu \mathrm{A}$, collimation $1.68 \mathrm{~mm}$ ). M ultiple fast-speed transverse scans from head to toes with $1-\mathrm{cm}$ intervals were performed, with a scan area of $576 \times 1,968 \mathrm{~mm}$ and a sample interval of $1 / 32$. A rectilinear scanner was used to detect density differences as the two concentrations of photon energy were projected through the subject. The scanner used a constant potential X-ray source at $78 \mathrm{kV}$ and a $\mathrm{K}$-edge filter to achieve a congruent beam of stable dual-energy radiation with effective energies of 38 and $70 \mathrm{keV}$. D ata were collected in maximal 205 scan lines $\times 120$ sample points (pixel size $4.8 \times 9.6 \mathrm{~mm}$ ). E ntrance radiation dose was minimal $(<0.02 \mathrm{mSv} / \mathrm{scan})$ (17). Total and subregional FM were derived according to computer algorithms (L unar software version 1.3; M adison, WI) provided by the manufacturer.

\section{Resting Energy Expenditure}

RE E was measured by an open-circuit indirect calorimetry system using a ventilated hood ( $O$ xycon $\beta$; J aeger, $W$ urzburg, The N etherlands) (18). M easurements were started in the early morning (8:30 A.M.). Patients were in a fasting state for at least $10 \mathrm{~h}$ and had a period of at least $30 \mathrm{~min}$ bed rest prior to the measurement during which subjects were comfortably lying on a bed in supine position. A fter stabilization, RE E was recorded during a period of $20 \mathrm{~min}$ and calculated from oxygen consumption and carbon dioxide production using the abbreviated $W$ eir formula.

\section{Dietary Intake}

In the cross-sectional study, dietary intake was assessed using the dietary history method with cross check. In the prospective study, food intake was recorded during $4 \mathrm{~d}$ before the start of the nutritional intervention and the mean intake of the $4 \mathrm{~d}$ was taken for analysis. The information was coded for computer nutrient analysis by the same trained dietician. The nutrient data base was derived from the Dutch food composition tables (19).

\section{Lung Function}

L ung function testing included spirometry ( $F E V_{1}$ and $F V C$ ), thoracic gas volumes (TLC), and diffusing capacity for carbon monoxide $\left(D L_{C O}\right)$ ( $M$ asterlab; J aeger, W urzburg, $\left.F R G\right)$. L ung function values were expressed as a percentage of predicted (20). Blood was drawn from the brachial artery at rest while breathing room air. A rterial pressures of oxygen and carbon dioxide $\left(\mathrm{Pa}_{2}, \mathrm{~Pa}_{\mathrm{CO}_{2}}\right)$ were analyzed on a blood gas analyzer (A BL 330; R adiometer, C openhagen).

\section{Assessment of Emphysema}

Evaluation of the presence and severity of emphysema was performed by high-resolution computed tomography (HRCT) using a commercial scanner (Somaton Plus; Siemens, E rlangen, FR G; voltage: $137 \mathrm{kV} \mathrm{p}$; current: $220 \mathrm{~mA}$; collimation: $1.0 \mathrm{~mm}$; scanning time: $1.0 \mathrm{~s})$. Five thin-section $\mathrm{CT}$ scans were obtained with the patient supine during breath hold at end-expiration: two scans of the upper and two scans of the lower lung zones at 3 and $6 \mathrm{~cm}$ above and below the carina and one scan at the carina. I mages were made at a concentration of $-800 \mathrm{H}$ ounsfield units $(\mathrm{HU})$ and window width of $1,600 \mathrm{HU}$, which is appropriate for lung detail. The severity and extent of emphysema of each scan was visually scored on a four-point scale independently by two observers according to the direct observational method of Sakai (21). For each of the lung sections, the score for the severity of emphysema was multiplied by the score for the extent; the resultant scores were subsequently summed to give a total HRCT score. Visual scores ranged from 0 (no emphysema) to 120 (severe emphysema). Patients with a visual score $<30$ were subtyped as chronic bronchitis and patients with a visual score $\geqslant 30$ were subtyped as emphysema (22).

HRCT is a sensitive technique for the evaluation of the presence and severity of emphysema; in patients with emphysema the densitometric parameters substantially differ from the corresponding values in patients with chronic bronchitis and healthy control subjects, regardless of the level of inspiration (23). 


\section{Collection and Analysis of Plasma Samples}

From all patients, blood was obtained in the fasting state by venipuncture at 9:00 P.M. Blood was collected in evacuated blood collection tubes (Sherwood M edical, St. L ouis, M O) containing ethylenediaminetetraacetic acid (EDTA). Plasma was separated from blood cells by centrifugation at $1,000 \mathrm{~g}$ for $10 \mathrm{~min}$ at $4^{\circ} \mathrm{C}$ within $1 \mathrm{~h}$ after collection. Plasma samples were stored at $-70^{\circ} \mathrm{C}$ until analysis. STNF-R 55 and -R 75 were measured using specific sandwich ELISA described elsewhere (24). In short, monoclonal antibodies ( $\mathrm{mA}$ b) M R 1-1 and M R 2-2 were coated on immunoassay plates ( N unc-Immuno Plate M axisorp, R oskilde, Denmark). The standards used were recombinant human STNF-R 55 and STNF-R 75. Specific biotin-labeled polyclonal rabbit anti human-sTNF-R I gG were used as detector reagents followed by streptavidin-peroxidase conjugate ( $D$ ako, G lostrup, D enmark). Photospectrometry $(450 \mathrm{~nm})$ was performed using a micro-E LISA autoreader. The detection limit of both assays was $100 \mathrm{pg} / \mathrm{ml}$. L eptin concentrations were measured using a double antibody sandwich E LISA assay using a $\mathrm{mA} b$ specific for human leptin. The lower concentration of detection was $0.25 \mathrm{ng} / \mathrm{ml}$ and the upper limit $50 \mathrm{ng} / \mathrm{ml}$. The intraand interassay variation were $9 \%$ and $12 \%$ respectively. The leptin concentrations of normal-weight healthy subjects ranged from 1 to 12 $\mathrm{ng} / \mathrm{ml}$.

Fasting serum concentration of glucose was determined by spectrophotometric analysis (Cobas M ira; H offmann-La R oche, B asel, Switzerland).

\section{Statistical Analysis}

Results are given as mean \pm SD. Differences between groups were statistically analyzed using an unpaired Student's t test. In the patients with leptin values below the detection limit $(0.25 \mathrm{ng} / \mathrm{ml})$, the value $0.25 \mathrm{ng} / \mathrm{ml}$ is used in the analysis. A fter curve estimation, linear, exponential or logarithmic Pearson product moment correlation coefficients were calculated. The relationship between leptin and the ST N F receptors was adjusted for $\mathrm{FM}$ and oral corticosteroid use using partial correlation analysis. A fter the simple correlations, a regression model was fitted to the data to select the variables that contributed to the explained variation in plasma leptin concentration. Significance was determined at the $5 \%$ level. D ata were analyzed according to the guidelines of A Itman and coworkers (25), using SPSS (Statistical Package for the Social Sciences, version 6.0 for W indows, SPSS Inc., Chicago, IL).

\section{RESULTS}

\section{Cross-sectional Study}

Characteristics of the study group stratified into the COPD subtypes (27 patients with emphysema, 15 patients with chronic bronchitis) are given in Table 1. The total group was characterized by severe lung function impairment. Patients with emphysema were characterized by a significantly lower $\mathrm{FEV}{ }_{1}, \mathrm{DL}_{\mathrm{CO}}$ and $\mathrm{Pa}_{\mathrm{O}_{2}}$ compared with those with chronic bronchitis. E mphysematous patients expressed also a significantly lower B M I owing to a significantly lower FM (mean difference $7.8 \mathrm{~kg} ; 95 \%$ confidence interval [Cl]: 3.2 to $12.4 \mathrm{~kg}$ ), whereas the groups were not different in FFM and in the prevalence of recent weight loss (emphysema: 14/27 versus chronic bronchitis: $6 / 15, p=0.340)$. D ietary intake was nearly significantly higher in the patients with the emphysematous subtype of COPD compared with the patients with the bronchitic subtype $(p=0.055)$, whereas no difference was seen in REE .

$M$ aintenance medication in the majority of patients consisted of theophylline (inhaled) $\beta_{2}$-agonists, and inhaled corticosteroids. Furthermore, 11 of 27 patients with emphysema versus eight of 15 patients with chronic bronchitis were on low-dose systemic corticosteroids (prednisone $\leqslant 10 \mathrm{mg} / \mathrm{d} ; \mathrm{p}=$ 0.322 ). No differences were seen in serum glucose between the patients with emphysema and chronic bronchitis (Table 1). On DXA-analysis, visceral FM estimated by trunk FM expressed as percentage of total FM was higher in patients with emphy- sema compared with chronic bronchitis $(52.1 \pm 5.4 \%$ versus $47.2 \pm 6.7 \%, p=0.023$ ). H owever, no influence of oral corticosteroid use on the distribution of body fat could be established.

A s expected based on the lower FM, mean detectable plasma leptin was significantly lower in the patients with emphysema compared with patients with chronic bronchitis ( Table 1). N ondetectable concentrations (below $0.25 \mathrm{ng} / \mathrm{ml}$ ) were found in eight of 27 patients with emphysema relative to two of 15 patients with chronic bronchitis. A large interindividual variation was seen, which is illustrated by the distribution of $\mathrm{FM}$ among the patients with leptin concentrations below the detection limit (Figure 1). The curvilinear correlation coefficient between leptin and FM was $0.74(p<0.001)$ in the patients with emphysema (Figure $1 A)$ and $0.80(p=0.001)$ in the patients with chronic bronchitis (Figure $1 B$ ). In addition, significant correlation coefficients between leptin and visceral $\mathrm{FM}$ expressed as percentage of total $\mathrm{FM}$ were revealed in the emphysematous patients $(r=0.45, p=0.030)$ and in the bronchitic patients $(r=0.77, p=0.003)$. The relation between leptin and FM or proportion of visceral FM was not affected by oral corticosteroid use.

A fter adjustment for FM and oral corticosteroid use as possible confounders, a significant partial correlation coefficient was found in the total group between leptin and ST NF-R 55 ( $r=$ $0.59, p<0.001)$ but not between leptin and STNF-R $75(r=$ $-0.08, p=0.633$ ). Figure 2 shows a striking difference in the relationship between ST NF-R 55 and leptin concentration between the COPD subtypes. Whereas in the patients with emphysema a highly significant partial correlation coefficient was found between STNF-R 55 and leptin after adjustment for F M and oral corticosteroid use $(r=0.81, p<0.001$; Figure 2A), such a relationship was not found in chronic bronchitis $(r=$ 0.29, $p=0.369$; Figure 2B ).

There are minor discrepancies in the number of subjects in Figures $1 \mathrm{~A}$ and $2 \mathrm{~A}$ and $1 \mathrm{~B}$ and $2 \mathrm{~B}$. These discrepancies can be explained by the fact that in two of 27 patients with emphysema and in one of 15 patients with chronic bronchitis FM was not measured.

On stepwise regression analysis, FM and ST N F-R 55 significantly explained $64 \%$ of the variation in plasma leptin concentration $(p<0.001)$. HRCT score as a measure of the extent of

TABLE 1 PATIENT CHARACTERISTICS

\begin{tabular}{|c|c|c|c|}
\hline & $\begin{array}{l}\text { Emphysema } \\
(n=27) \\
(\text { mean } \pm \text { SD })\end{array}$ & $\begin{array}{l}\text { Chronic Bronchitis } \\
(n=15) \\
(\text { mean } \pm \text { SD })\end{array}$ & $\mathrm{p}$ Value \\
\hline Age, yr & $67 \pm 8$ & $67 \pm 5$ & 0.855 \\
\hline $\mathrm{BMI}, \mathrm{kg} / \mathrm{m}^{2}$ & $21.6 \pm 3.0$ & $25.1 \pm 3.3$ & 0.001 \\
\hline $\mathrm{FFM}, \mathrm{kg}$ & $47.0 \pm 6.7$ & $48.7 \pm 7.1$ & 0.440 \\
\hline $\mathrm{FM}, \mathrm{kg}$ & $15.7 \pm 6.4$ & $23.5 \pm 7.6$ & 0.001 \\
\hline Dietary intake, kcal/24 h & $2,144 \pm 536$ & $1,803 \pm 533$ & 0.055 \\
\hline REE, kcal/24 h & $1,494 \pm 194$ & $1,588 \pm 232$ & 0.169 \\
\hline FVC, \% pred & $86 \pm 14$ & $83 \pm 15$ & 0.434 \\
\hline $\mathrm{FEV}_{1}, \%$ pred & $33 \pm 10$ & $43 \pm 14$ & 0.016 \\
\hline TLC, \% pred & $120 \pm 19$ & $118 \pm 17$ & 0.663 \\
\hline D Lco, $_{\text {, }} \%$ pred & $45 \pm 17$ & $71 \pm 19$ & $<0.001$ \\
\hline $\mathrm{Pa}_{2}, \mathrm{KPa}$ & $9.4 \pm 1.4$ & $10.5 \pm 0.9$ & 0.012 \\
\hline $\mathrm{Pa}_{\mathrm{CO}_{2}}, \mathrm{kPa}$ & $5.8 \pm 0.7$ & $5.6 \pm 1.0$ & 0.354 \\
\hline sTNF-R55, ng/ml & $0.65 \pm 0.32$ & $0.65 \pm 0.30$ & 0.992 \\
\hline sTNF-R75, ng/ml & $1.57 \pm 0.39$ & $1.66 \pm 0.46$ & 0.512 \\
\hline Glucose, $\mathrm{mmol} / \mathrm{L}$ & $5.9 \pm 0.9$ & $6.5 \pm 1.5$ & 0.121 \\
\hline Leptin,* ng/ml & $2.6 \pm 2.7$ & $5.1 \pm 3.0$ & 0.020 \\
\hline
\end{tabular}

* Mean value of detectable leptin concentrations: $n=19$ (emphysema) and $n=13$ (bronchitis) (lower detection limit of the assay: $0.25 \mathrm{ng} / \mathrm{ml}$. 

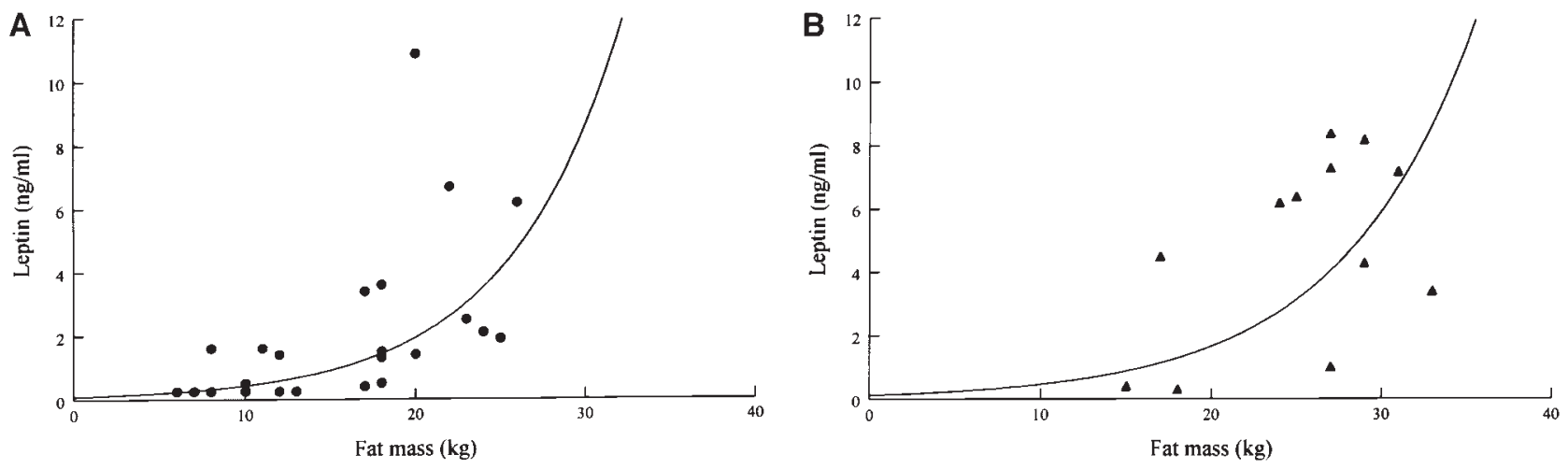

Figure 1. Relationship between leptin concentration and fat mass $(A)$ in patients with emphysema $(r=0.74, p<0.001)$ and $(B)$ in patients with chronic bronchitis $(r=0.80, p=0.001)$.

emphysema, FFMI as a measure of functional tissue depletion, and oral corticosteroid use were excluded from the model (Table 2).

\section{Prospective Study}

Prospectively, 17 male patients with COPD suffering from depletion of body weight and/or FFM were studied. In this group, mean age ( \pm SD) amounted to $65 \pm 7 \mathrm{yr}, \mathrm{BM} \mathrm{I} 19.4 \pm$ $2.1 \mathrm{~kg} / \mathrm{m}^{2}, \mathrm{FFM} 44.5 \pm 5.0 \mathrm{~kg}, \mathrm{FM} 13.9 \pm 6.5 \mathrm{~kg}, \mathrm{FEV}_{1} 30 \pm 10 \%$ pred, and $D L_{C O} 37 \pm 14 \%$ pred. In these patients the $D L_{C O}$, as a less precise measure of the extent of emphysema, was comparable to the $D L_{\text {co }}$ of the patients with emphysema described in the cross-sectional study and significantly lower than in the bronchitic patients $(p<0.05)$. It is known that HRCT assessment of emphysema highly correlates with the $D L_{c o}$. In the study of Lamers (26) a high prevalence $(93 \%)$ of HRCTscored emphysema was observed in patients with a $D L_{c o}<$ $50 \%$ of predicted and a low prevalence (19\%) in patients with a $D L_{\text {co }} \geqslant 50 \%$ of predicted. Furthermore, $D L_{\text {co }}$ (percentage of predicted) significantly inversely correlated with the H R CT emphysema score (26). M ean weight gain after 8 wk of nutritional supplementation was $2.9 \pm 2.7 \mathrm{~kg}$, consisting of $1.6 \pm$ $2.0 \mathrm{~kg} F \mathrm{FM}$.

In most patients (10 of 17) leptin concentrations were undetectable. Serum glucose amounted to $6.2 \pm 1.0 \mathrm{mmol} / \mathrm{L}$ mean \pm SD. Similar to the cross-sectional study, maintenance medication in the majority of patients consisted of theophylline (inhaled) $\beta_{2}$-agonists, and inhaled corticosteroids. Fur- thermore, nine of 17 patients were using low-dose systemic corticosteroids (prednisone $\geqslant 10 \mathrm{mg} / \mathrm{d}$ ). No differences in leptin, sT NF receptors, or glucose were seen between patients who were receiving oral corticosteroids and patients who were not.

Figure 3 shows that mean dietary intake before the start of the nutritional intervention was logarithmically inversely related to baseline leptin concentration divided by FM ( $r=$ $-0.50, p=0.047$ ) while no relationship was found between REE and leptin. B aseline leptin concentration, also divided by $\mathrm{FM}$, was in turn logarithmically inversely related to the body weight change (but not specifically to the changes in FFM or $F M)$ reached after $8 w k$ of nutritional intervention $(r=-0.60$, $\mathrm{p}=0.017$; Figure 4).

The discrepancies in the number of subjects in Figures 3 and 4 can be addressed to the fact that in one of 17 patients dietary intake was not assessed and in two of 17 patients the change in body weight was not measured.

\section{DISCUSSION}

This is the first clinical study showing that enhanced concentrations of leptin are related to proinflammatory status in patients with COPD. A significant relationship between plasma concentrations of leptin and ST NF-R 55 adjusted for fat mass and oral corticosteroid use was found, particularly in the emphysematous subtype. Subsequently in a group of depleted emphysematous patients with COPD, baseline leptin concentration was in turn inversely related to baseline dietary intake
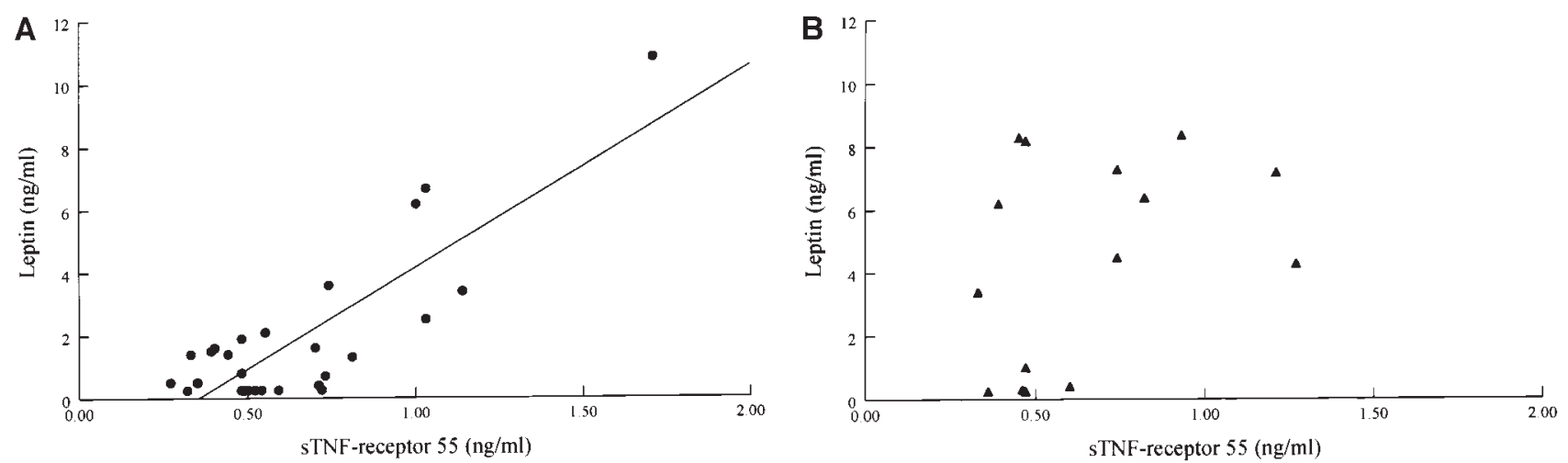

Figure 2. After adjustment for fat mass and oral corticosteroid use, leptin concentration is significantly related to sTNF-R55 in emphysema (A: $r=0.81, p<0.001)$, but not in chronic bronchitis $(B: r=0.29, p=0.369)$. 
TABLE 2

\section{INDEPENDENT CONTRIBUTORS TO THE EXPLAINED VARIATION IN PLASMA LEPTIN CONCENTRATION ON STEPWISE REGRESSION ANALYSIS}

\begin{tabular}{lcr}
\hline & Cumulative $\mathrm{R}^{2}$ & $\mathrm{p}$ Value \\
\hline FM, kg & 0.46 & $<0.001$ \\
STNF-R55, ng/ml & 0.64 & $<0.001$ \\
HRCT score, O-120 & & 0.728 \\
FFMI, kg/m & & 0.717 \\
Oral corticosteroid use, no/yes & & 0.432 \\
\hline
\end{tabular}

Definition of abbreviation: $\mathrm{R}^{2}=$ coefficient of determination.

as well as to the weight change after $8 \mathrm{wk}$ of nutritional intervention.

L eptin was found to be associated with FM in line with the reported feedback mechanism involved in the regulation of FM . B ecause plasma leptin was unrelated to FF M I (as a measure of functional tissue depletion), it appears that this feedback mechanism does not consider global body composition in patients with COPD. We were however not able to compare leptin levels in COPD with normal leptin levels, because we did not include a healthy age-matched control group. The difference in plasma leptin between emphysema and chronic bronchitis was expected because of significant differences in FM. The lower leptin levels in emphysema could be related to the higher dietary intake revealed in this subgroup, according to the normal feedback mechanism of fat mass by leptin. The fact that dietary intake was increased in the patients with emphysema, despite a similar REE and prevalence of recent weight loss compared with the patients with chronic bronchitis, could be explained by an increased "wasting" of energy related to a previously reported increased activity-related energy expenditure (27).

The fact that FM could only partly explain the variation in leptin concentrations suggests that other factors might be involved. In this study we identified a significant relationship between leptin and STNF-R 55 concentrations in patients with COPD after adjustment for FM and oral corticosteroid use. Further indications for involvement of inflammation in the pathogenesis of weight loss in COPD are given by observations of others. $U$ sing an immunoradiometric assay, di Francia and coworkers demonstrated elevated TNF- $\alpha$ concentrations in serum of patients with COPD suffering from weight loss compared with weight-stable patients (13). In contrast de G odoy,

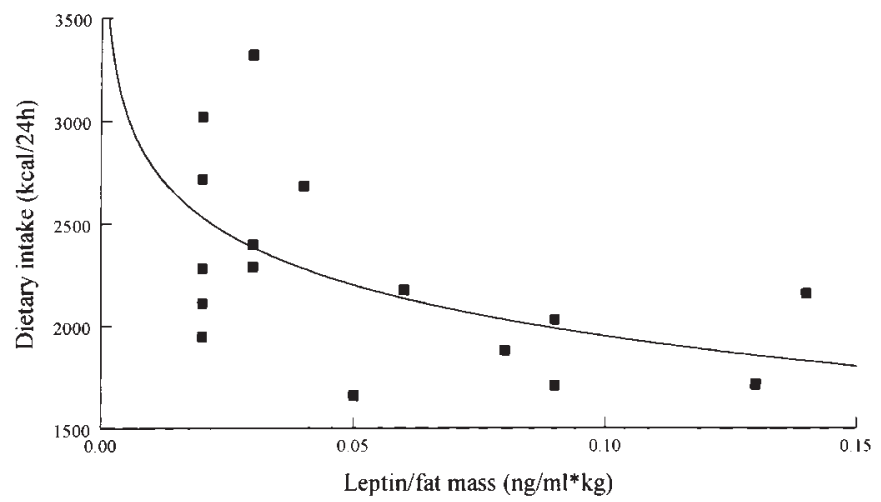

Figure 3. Inverse relationship between dietary intake before nutritional therapy and baseline plasma leptin concentration divided by fat mass in depleted patients with COPD $(r=-0.50, p=0.047)$

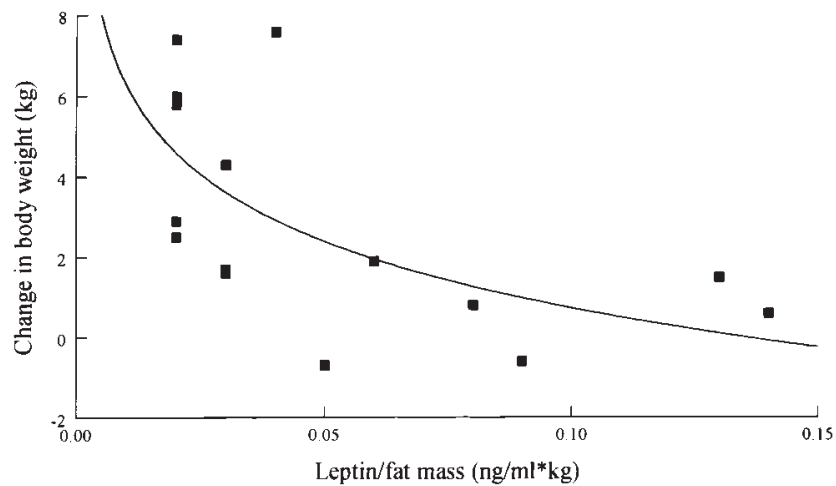

Figure 4. Inverse relationship between the change in body weight after 8 wk of nutritional therapy and baseline plasma leptin concentration divided by fat mass in depleted patients with COPD $(r=-0.60, p=0.017)$.

using an E LISA assay which measured only biologically active TNF- $\alpha$, did not find differences in TNF- $\alpha$ serum concentrations between weight-losing and weight-stable patients with COPD (14). The TNF- $\alpha$ production of peripheral monocytes of patients with recent weight loss was however enhanced after stimulation with lipopolysaccharide (LPS) when compared with weight-stable patients with COPD and control subjects (14).

The reason for the discrepancy between the correlations between leptin and ST N F-R 55 and leptin and ST N F-R 75 is unclear, but other studies from our group have shown similar results. In lung cancer, patients who exhibited a weight loss $\geqslant 10 \%$ tended to exhibit a higher level of STNF-R 55 compared with patients with weight loss $<10 \%(p=0.06)$, whereas there was no difference in STNF-R 75 levels. In accordance, the percentage of weight loss was significantly correlated with ST NF-R $55(r=0.59, p=0.02)$ but not with ST NF-R 75 (28). In another study in lung cancer, plasma STNF-R 55 was significantly higher in patients with a REE $\geqslant 110 \%$ of the $\mathrm{H}$ arris and $B$ enedict prediction equations and suffering from recent weight loss, whereas plasma ST NF-R 75 was not different (29). So it seems that sT N F-R 55 and ST N F-R 75 exert some differential effects on weight maintenance and energy balance; STNF-R 55 has shown to be related to both dietary intake and metabolic parameters such as weight loss and REE, whereas STNF-R 75 has not. In addition, ST NF-R 55 may be more sensitive to metabolic changes than STNF-R 75.

Experimental animal studies have provided evidence for a link between proinflammatory cytokines and leptin. Cytokine treatment (TNF- $\alpha$, interleukin-1 [IL-1]) of fasted hamsters increased concentrations of leptin in the circulation and leptin messenger RNA (mRNA) in adipose tissue. The increase in circulating leptin concentrations correlated with a decrease in food intake (11). The hypothesis that cytokine induction of leptin may play a significant role in the anorexia and cachexia of inflammatory diseases was further illustrated by Sarraf showing that administration of the proinflammatory cytokines TNF- $\alpha, I L-1$, and to a lesser extent leukemia inhibitory factor produced a prompt and dose-dependent increase in serum leptin and leptin mRNA expression in the adipose tissue of mice. In contrast, the cytokines IL-10, IL-4, and ciliary neurotrophic factor, not known to induce anorexia or a decrease in intake, did not affect leptin gene expression or serum leptin concentrations (12). No data are available yet on leptin mRNA expression in FM of patients suffering from cachexia. 
Furthermore, it should be pointed out that leptin gene expression may be different between rodents and humans.

On the opposite end of the energy balance spectrum, recent data have suggested a key role for TNF- $\alpha$ in the insulin resistance of obesity and of noninsulin-dependent diabetes mellitus (NID D M ) (30). In humans, a strong positive correlation was found between the degree of obesity based on the $B M I$, hyperinsulinemia, and relative TNF- $\alpha$ mRNA concentrations in adipose tissue (31). The results of another recent study did however not reveal a significant relationship between individual insulin sensitivity on the one hand and circulating concentrations of TNF- $\alpha$ and leptin on the other in patients with offspring NID D M (32). No significant relationship was found between leptin and TN F- $\alpha$ in these patients in contrast to the findings of our group. Based on the present study, we can not exclude an influence of alterations in insulin sensitivity, possibly induced by oral corticosteroid therapy, on the observed relationship between STNF receptors and leptin in patients with CO PD. Jakobsson and coworkers reported nevertheless that insulin resistance was not exhibited by patients with advanced CO PD compared with healthy subjects (33).

A substantial proportion of patients used oral corticosteroids as maintenance medication. R eports concerning the effects of oral corticosteroid use on leptin are contradictory. Two days of oral corticosteroid administration (dexamethasone $1.5 \mathrm{mg} / \mathrm{d}$ ) in healthy subjects resulted in significantly increased serum concentrations of leptin, owing to enhanced leptin messenger R N A concentrations, and of insulin, but not of serum glucose (34). In addition, another study reported that administration of dexamethasone during $4 \mathrm{~d}(2.5 \mathrm{mg} / \mathrm{d})$ to healthy lean and obese subjects induced a significant increase in plasma leptin concentrations. Furthermore, significant correlations between the change in plasma leptin on the one hand and BM I, baseline plasma leptin, and plasma dexamethasone concentrations on the other were revealed (35). In lean healthy male volunteers, Tataranni investigated whether acute intravenous administration of glucocorticosteroids (methylprednisolone $125 \mathrm{mg}$ ) or prolonged oral treatment $(40 \mathrm{mg} / \mathrm{d}$ during $4 \mathrm{~d}$ ) affected plasma leptin concentrations. A cute administration had no effects on insulin, free fatty acids (FFA ), or leptin concentrations as compared with placebo, whereas prolonged administration significantly increased fasting concentrations of insulin, but not of glucose, FFA, or leptin (36). In the crosssectional part of this study we found no influence of prolonged oral corticosteroid use on the relation of leptin with $\mathrm{FM}$ or with STNF-R 55. A Iso concentrations of leptin and STNF receptors were comparable between patients using prednisone or not. I n the prospective study, no differences in leptin, sT N F receptors, or glucose were seen between patients who were receiving oral corticosteroids and patients who were not.

A nother well known effect of chronic use of glucocorticoids is shifting in body fat distribution toward a higher visceral fat compartment. Visceral adiposity has furthermore been associated with increased serum leptin concentrations in healthy male subjects, in contrast to females (37). In the crosssectional study indeed a significant, positive relationship was established between the proportion of visceral fat and leptin, but no influence of chronic oral corticosteroid use on fat distribution was seen.

O verall, on the basis of the present study, the impact of the presumed effects of oral corticosteroids on leptin metabolism and on the relationship between leptin and STNF receptors appears marginal.

The cause of the systemic inflammation in patients with COPD is unknown. In our study group the relation between leptin and STNF-R 55 was stronger in the patients with emphy- sema than in those with chronic bronchitis. This difference could be related to a larger proportion of depleted patients or to other factors in the pathophysiology of the disease such as chronic or intermittent hypoxemia. G hezzi and coworkers previously demonstrated that LPS-stimulated human monocytes increased their release of TNF- $\alpha$ and IL-1 during hypoxia (38). More recently, $\mathrm{Hempel}$ and coworkers showed that hypoxia also caused significant changes in the LPS-stimulated release of the cytokines TNF $-\alpha$ and IL $-1 \beta$ by the human alveolar macrophage. These changes could be mediated by an altered synthesis of anti-inflammatory prostaglandins (PG), e.g., $P \mathrm{E}_{2}$, or by a direct effect of hypoxemia on gene regulation caused by changes in cell oxidant tone (39). In addition, in patients with chronic bronchitis, the FM was significantly higher than in emphysema, so in this subgroup of patients the relation between $\mathrm{FM}$, leptin, and dietary intake is probably less disturbed by the presence of a systemic inflammatory response. We recognize, however, that the relationship between leptin and systemic inflammation may also be related to the nutritional status which was better in the bronchitic patients than in the emphysematous patients.

The results of this study may have important therapeutic implications. Despite an overall positive effect of nutritional support on body composition and functional performance in depleted patients with COPD, we and others have reported that a proportion of the patients did not respond to this treatment (40). Based on the present findings, it may be argued whether oral nutritional support alone is an appropriate treatment strategy in depleted patients with COPD suffering from anorexia owing to the presence of a systemic inflammatory response. In line with this hypothesis we showed in a subgroup of predominantly emphysematous depleted patients with CO PD that baseline plasma leptin concentrations were inversely related to baseline dietary intake and to the change in body weight after 8 wk of nutritional therapy. Further longitudinal studies are indicated to confirm this proposed cytokine-leptin hypothesis in pulmonary cachexia which may then open a novel approach to combat this significant comorbidity in COPD.

\section{References}

1. Zhang, Y., R. Proenca, M. M affei, M. Barone, L. Leopold, and J. M. Friedman. 1994. Positional cloning of the mouse obese gene and its human homologue. Nature 372:425-432.

2. Tartaglia, L. A ., M. D embski, X. Weng, N. Deng, J. Culpepper, R. D evos, G.J . R ichards, L. A . Campfield, F. T. Clark, J . D eeds, et al. 1995. I dentification and expression cloning of a leptin receptor, OB-R . Cell 83:1263-1271.

3. Chen, H., O. Charlat, L. A . Tartaglia, E. A. Woolf, X. Weng, S. J . Ellis, N. D. Lakey, J . Culpepper, K. J. M oore, R. E. B reitbart, G. M. D uyk, R. I. Tepper, and J. P. M orgenstern. 1996. Evidence that the diabetes gene encodes the leptin receptor: identification of a mutation in the leptin receptor gene in db/db mice. Cell 84:491-495.

4. Halaas, J. L., K. S. Gajiwala, M. M affei, S. L. Cohen, B. T. Chait, D. R abinowitz, R. L. Lallone, S. K. Burley, and J. M. Friedman. 1995. W eight-reducing effects of the plasma protein encoded by the obese gene. Science 269:543-546.

5. Friedman, J. M. 1997. The alphabet of weight control. N ature 385:119-120.

6. Collins, S., C. M. Kuhn, A. E. Petro, A. G. Swick, B. A. Chrunyk, and R. S. Surwit. 1996. R ole of leptin in fat regulation. Nature 380:677.

7. Considine, R. V., M. K. Sinha, M. L. Heiman, A. K riauciunas, T. W. Stephens, M. R. Nyce, J. P. O hannesian, C. C. M arco, L. J. M cK ee, T. L. B auer, and J. F. Caro. 1996. Serum immunoreactive leptin concentrations in normal-weight and obese humans. N. E ngl. J. M ed. 334: 292-295.

8. Engelen, M. P. K. J., A. M. W. J . Schols, W. C. B aken, G.J. W esseling, and E. F. M. W outers. 1994. Nutritional depletion in relation to respiratory and peripheral skeletal muscle function in out-patients with COPD . E ur. Respir. J . 7:1793-1797.

9. Schols, A. M. W. J., P. B. Soeters, R. M ostert, W. H. M. Saris, and E. F. M. 
W outers. 1991. E nergy balance in COPD. A m. Rev. Respir. D is. 143: 1248-1252.

10. Schols, A. M. W. J., E. W. H. M. Fredrix, P. B. Soeters, K. R. Westerterp, and E. F. M. Wouters. 1991. R esting energy expenditure in patients with chronic obstructive pulmonary disease. A m. J. Clin. Nutr. 54:983-987.

11. Grunfeld, C., C. Z hao, J. Fuller, A . Pollock, A . M oser, J. Friedman, and K. R. Feingold. 1996. Endotoxin and cytokines induce expression of leptin, the ob gene product, in hamsters. J. Clin. Invest. 9:2152-2157.

12. Sarraf, P., R. C. Frederich, E. M. Turner, G. M a, N. T. Jaskowiak, D. J. Rivet, J. S. Flier, B. B. Lowell, D. L. Fraker, and H. R. A lexander. 1997. M ultiple cytokines and acute inflammation raise mouse leptin levels: potential role in inflammatory anorexia. J. Exp. M ed. 1:171-175.

13. Di Francia, M., D. Barbier, J. L. M ege, and J. Orehek. 1994. Tumor necrosis factor al pha levels and weight loss in chronic obstructive pulmonary disease. A m. J. Respir. Crit. Care M ed. 150:1453-1455.

14. de Godoy, I., M. D onahoe, W. J. Calhoun, J. M ancino, and R. M. R ogers. 1996. Elevated TNF- $\alpha$ production by peripheral blood monocytes of weight-losing COPD patients. A m. J. Respir. Crit. Care M ed. 153: 633-637.

15. A merican Thoracic Society. 1995. Standards for the diagnosis and care of patients with chronic obstructive pulmonary disease. A m. J. Respir. Crit. Care M ed. 152:s77- s120.

16. W esterterp, K. R ., L. W outers, and W. D . van M arken Lichtenbelt. 1995. The $M$ aastricht Protocol for the measurement of body composition and energy expenditure with labeled water. 0 besity Res. 3:49-57.

17. M azess, R. B., H. B arden, J. P. B isek, and J. H anson. 1990. D ual-energy $\mathrm{x}$-ray absorptiometry for total body and regional bone-mineral, and soft tissue composition. A m. J. Clin. N utr. 51:1106-1112.

18. Schols, A . M. W. J., P. F. Schoffelen, H. Ceulemans, E. F. M. W outers, and W. H. Saris. 1992. M easurement of resting energy expenditure in patients with COPD in a clinical setting. J.P.E.N. 16:364-368.

19. Stichting N ederlands $V$ oedingsstoffenbestand. 1996. NE V O tabel. V oorlichtingsbureau voor de $\mathrm{V}$ oeding, $\mathrm{D}$ en $\mathrm{H}$ aag.

20. Quanjer, P. H., editor. 1993. Standardized lung function testing. E ur. Respir. J . 6(Suppl. 16):1-52.

21. Sakai F., G. Gamsu, J. G. Im, and C. S. R ay. 1987. Pulmonary function abnormalities in patients with CT-determined emphysema. J. Comp. A ssist. Tomogr. 11:963-968.

22. Engelen, M. P. K. J., A . M . W. J. Schols, R. J. L. Lamers, G. A . K. H eidendal, and E. F. M. Wouters. 1996. Influence of alveolar wall destruction on body composition and physiological function in patients with chronic obstructive pulmonary disease (abstract). A m. J. Respir. Crit. Care M ed. 53:A 454.

23. Lamers, R. J., G. R. Thelissen, A. G. Kessels, E. F. W outers, and J. M. van Engelshoven. 1994. Chronic obstructive pulmonary disease: evaluation with spirometrically controlled CT lung densitometry. Radiology 193:109-113.

24. L eeuwenberg, J. F. M., G. M. M . A . J eunhomme, W. A . B uurman. 1994. Slow release of soluble TNF-receptors by monocytes in vitro. J. Immunol. 152:4036-4043.
25. A Itman, D. G., S. M. G ore, M. J . G ardner, and S. J. Pocock. 1983. Statistical guidelines for contributors to medical journals. Br. M ed. J. 286 (Clin. Res. E d.):1489-1493.

26. L amers, R. J. S. 1998. Q uantitative CT of the $L$ ungs. Technical A spects and Clinical Studies (Thesis). D atawyse B oekproducties, M aastricht.

27. B aarends, E. M ., A . M . W. J. Schols, D. L. E. Pannemans, K. R. W esterterp, and E. F. M. W outers. 1997. Total free living energy expenditure in patients with severe chronic obstructive pulmonary disease. A m. J. Respir. Crit. Care M ed. 155:549-554.

28. Simons, J. P. F. H. A . 1997. Cancer Cachexia. Thesis, D atawyse B oekproducties, M aastricht.

29. Staal-van den B rekel, A . J., M. A . D entener, A . M. W. J. Schols, W. A . B uurman, and E. F. M. Wouters. 1995. Increased resting energy expenditure and weight loss are related to a systemic inflammatory response in lung cancer patients. J. Clin. O ncol. 13:2600-2605.

30. H otamisligil, G. S., and B. Spiegelman. 1994. Tumor necrosis factor $\alpha$ : a key component of the obesity-diabetes link. D iabetes 43:1271-1278.

31. K ern, P. A ., M. Saghizadeh, J. M. Ong, R. J. B osch, R. D eem, and R. B. Simsolo. 1995. The expression of tumor necrosis factor in human adipose tissue. J. Clin. Invest. 95:2111- 2119.

32. Kellerer, M., K. R ett, W. R enn, L. G roop, and H. U . H äring. 1995. Circulating TNF-alpha and leptin levels in offspring of NID D M patients do not correlate to individual insulin sensitivity. Horm. M etab. Res. 28:737-743.

33. Jakobsson, P., L. J orfeldt, and H. V on Schenck. 1995. Insulin resistance is not exhibited by advanced chronic obstructive pulmonary disease patients. Clin. Physiol. 15:547-555.

34. Papaspyrourao, S., S. H. Schneider, R. N. Petersen, and S. K. Fried. 1997. D examethasone increases leptin expression in humans in vivo. J.C.E.M. 82:1635-1637.

35. D agogoJ ack, S., G. Selke, A. K. M elson, and J. W. N ewcomer. 1997. R obust leptin secretory responses to dexamethasone in obese subjects. J.C.E.M. 82:3230-3233.

36. Tataranni, P. A ., R. Pratley, M. M affei, and E. R avussin. 1997. A cute and prolonged administration of glucocorticoids (methylprednisolone) does not affect plasma leptin concentration in humans. Int. J. O besity 21:327-330.

37. R onnemaa, T., S. L. K aronen, A. R issanen, M. K oskenvuo, and V. A . K oivisto. 1997. R elation between plasma leptin levels and measures of body fat in identical twins discordant for obesity. A nn. Intern. M ed. 126:26-31.

38. G hezzi, P., C. A . D inarello, M . B ianchi, E. Rosandich, J . E. R epine, and C. W. White. 1991. H ypoxia increases production of interleukin-1 and tumor necrosis factor by human mononuclear cells. Cytokine 3:189-194.

39. H empel, S. L., M. M. M onick, and G. W. H unninghake. 1996. E ffect of hypoxia on release of IL-1 and TNF by human alveolar macrophages. A m. J. Respir. Cell Mol. Biol. 14:170- 176.

40. Schols, A . M. W. J ., P. B. Soeters, R . M ostert, R . J. Pluymers, and E. F. M . Wouters. 1995. Physiological effects of nutritional support and anabolic steroids in COPD patients. A m. J. Respir. Crit. Care M ed. 152: 1268-1274. 